\title{
Cervical Cancer Clinical Regional Lymph Nodes TNM Finding v7
}

National Cancer Institute

\section{Source}

National Cancer Institute. Cervical Cancer Clinical Regional Lymph Nodes TNM Finding v7. NCI Thesaurus. Code C89496.

A clinical finding about one or more characteristics of cervical cancer, following the rules of the TNM AJCC V7 classification system as they pertain to staging of regional lymph nodes. 